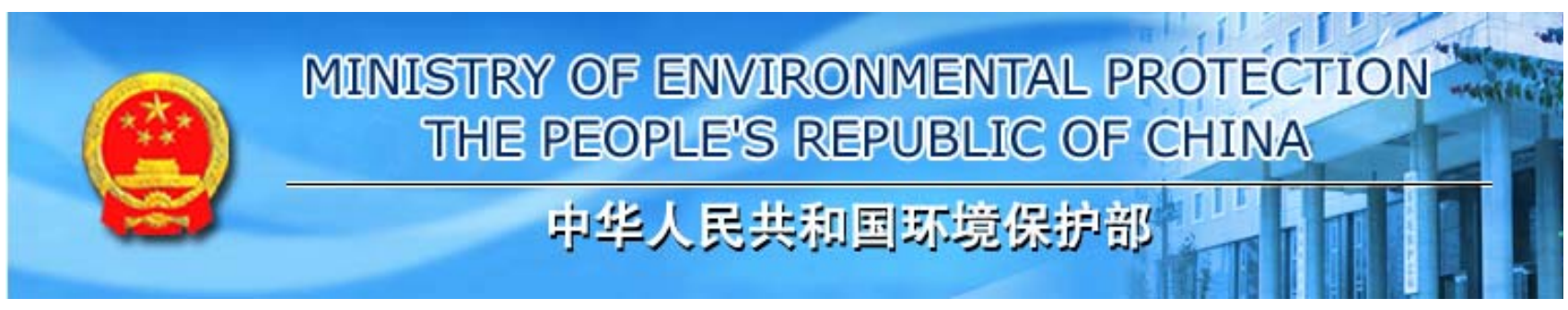

\title{
中文版
}

BIG5

Sitemap

Statement

Search

Mission

Contact us

Current Location:HOME->Policies and Regulations->Laws->Environmental Laws

\section{Law of the People's Republic of China on Prevention and Control of Water Pollution}

1984-05-11

Article type: Redistributed

\section{CHAPTER I GENERAL PROVISIONS}

Article 1 This Law is formulated for the purpose of preventing and controlling water pollution, protecting and improving the environment, safeguarding human health, ensuring the effective use of water resources and facilitating the development of socialist modernization.

Article 2 This Law shall apply to the prevention and control of pollution of rivers, lakes, canals, irrigation channels, reservoirs and other surface water bodies and of groundwater within the territory of the People's Republic of China.

This Law is not applicable to the prevention and control of marine pollution, which is provided for by a separate law.

Article 3 Competent departments under the State Council and local People's governments at various levels shall incorporate the protection of the water environment into their plans and adopt ways and measures to prevent and control water pollution.

Article 4 The environmental protection departments of the People's governments at all levels shall be the organs exercising unified supervision and management of the prevention and control of water pollution.

Navigation administrative offices of transportation departments at various levels shall be the organs exercising supervision and management of pollution from ships.

Water conservancy administration departments, public health administration departments, geological and mining departments, municipal administration departments and water sources protection agencies on major rivers of People's governments at various levels shall, through performing their respective functions and in conjunction with environmental protection departments, implement supervision and management of the prevention and 
control of water pollution.

Article 5 All units and individuals shall have the duty to protect the water environment and the right to supervise any act that pollutes or damages the water environment and to inform against the polluter.

Any unit or individual that has suffered losses directly from a water pollution hazard shall have the right to claim damages from and demand the elimination of the hazard by the polluter.

\section{CHAPTER II ESTABLISHMENT OF STANDARDS FOR WATER ENVIRONMENT QUALITY AND FOR DISCHARGE OF WATER POLLUTANTS}

Article 6 The environmental protection department of the State Council shall establish national water environment quality standards.

The People's governments of provinces, autonomous regions, and municipalities directly under the Central Government may establish their own local, supplementary standards for those items not specified in the national water environment quality standards and report the same to the environmental protection department of the State Council for the record.

Article 7 The environmental protection department of the State Council shall, in accordance with the national water environment quality standards and the country's economic and technological conditions, establish national pollutant discharge standards.

The People's governments of provinces, autonomous regions and municipalities directly under the Central Government may establish its local standards for the discharge of water pollutants for items not specified in the national standards; with regard to items already specified in the national standards, it may set local standards which are more stringent than the national standards. The local standards for the discharge of water pollutants must be reported to the environmental protection department of the State Council for the record.

Those who discharge pollutants into any water body where local pollutant discharge standards have been established shall observe such local standards.

Article 8 The environmental protection department of the State Council and the People's governments of provinces, autonomous regions, and municipalities directly under the Central Government shall amend in due time their respective water environment quality standards and pollutant discharge standards in accordance with the requirements of water pollution prevention and control and with the country's economic and technological conditions.

http://english.mep.gov.cn/Policies_Regulations/laws/environmental_laws/200710/t200... 2009-10-5 


\section{CHAPTER III SUPERVISION AND MANAGEMENT OF PREVENTION AND CONTROL OF WATER RESOURCES}

Article 9 Competent departments under the State Council and local People's governments at various levels shall, in the process of developing, utilizing, regulating and allocating water resources, make integrated plans for maintaining proper river flows, proper water levels of lakes and reservoirs and proper groundwater tables, in order to sustain the natural purification capacity of water bodies.

Article 10 The prevention and control of water pollution shall be planned in a unified way on the basis of river basins or regions. Water pollution prevention and control plans for major river basins designated by the state shall be drawn up by the environmental protection department of the State Council in consultation with the competent planning department, the water conservancy administration department and other competent departments under the State Council, and the People's governments of involved provinces, autonomous regions and municipalities under the Central Government, and shall be reported to the State Council for approval.

Water pollution prevention and control plans for other river basins involving two or more provinces or counties shall, in accordance with the plans for major river basins designated by the state and with the local practical situations, be drawn up by the environmental protection department in consultation with the water conservancy administration department and other competent departments of the People's government at or above the provincial level, and the local people's governments involved, and shall be reported to the State Council or the people's government at the provincial level for approval. Plans for other river basins involving two or more counties but not involving different provinces shall be reported by the People's government of the province to the State Council for the record.

The approved plans shall serve as the bases for the prevention and control of water pollution. Any amendment to an approved plan must be approved by the original approving department.

Local People's governments at or above the county level shall, in accordance with the water pollution prevention and control plans for river basins already approved according to law, organize to formulate plans for the prevention and control of water pollution within their respective administrative areas, and shall incorporate such plans into the medium- and long- term plans and annual plans for the national economy and social development of their respective administrative areas.

Article 11 Competent departments under the State Council and local People's governments at various levels shall make rational plans for the placement of industry, and see to it that enterprises causing water pollution are modified and technically renovated, adopting comprehensive prevention and control measures, raising the frequency of water reuse, utilizing resources rationally and reducing the quantity of waste water and pollutants discharged.

http://english.mep.gov.cn/Policies_Regulations/laws/environmental_laws/200710/t200... 2009-10-5 
Article 12 For water bodies at scenic or historic sites, important fishery water bodies and other water bodies of special economic or cultural value, people's governments at or above the county level may delineate protected zones and take measures to ensure that the water quality in those protected zones complies with the standards for their designated uses.

Article 13 New construction projects, extensions, or reconstruction projects which discharge pollutants into water bodies directly or indirectly and installations on water shall be subject to the state provisions concerning environmental protection for such projects.

The environmental impact statement of a construction project shall assess the water pollution hazards the project is likely to produce and its impact on the ecosystem, with prevention and control measures provided therein; the statement shall be submitted, according to the specified procedure, to the environmental protection department concerned for review and approval. The setting up of sewage outfalls within any water conservancy projects such as canals, irrigation channels and reservoirs shall be approved by the relevant department in change of water conservancy.

Facilities for the prevention and control of water pollution at a construction project must be designed, built and commissioned together with the principal part of the project. Such facilities must be inspected by the environmental protection department; if they do not conform to the specified requirements, the said project shall not be permitted to be put into operation or to use.

The environmental impact statement shall include views of units and residents where the construction project is to be located.

Article 14 Enterprises and institutions that discharge pollutants directly or indirectly into a water body shall, pursuant to the provisions of the environmental protection department of the State Council, report to and register with their local environmental protection department their existing treatment and discharge facilities for pollutants and the categories, quantities and concentrations of pollutants discharged under their normal operating conditions and also submit to the same department the relevant technical information concerning the prevention and control of water pollution.

The pollutant discharging units mentioned in the preceding paragraph shall report in time if any substantial change occurs in the categories, quantities or concentrations of the water pollutants discharged. Their water pollutant treatment facilities must be kept in normal use. When such facilities are to be dismantled or left idle, prior approval must be obtained from the environmental protection department of the local People's government at or above the county level.

http://english.mep.gov.cn/Policies_Regulations/laws/environmental_laws/200710/t200... 2009-10-5 
Article 15 Enterprises and institutions discharging pollutants into a water body shall pay a discharge fee as provided for by the state. If the discharge of pollutants exceeds the limits set by national or local standards, they shall pay a fee for excess discharge according to state provisions.

The income derived from the discharge fee and the fee for excess discharge must be used for the prevention and control of pollution and shall not be appropriated for other purposes.

Enterprises and institutions discharging pollutants in excess of the prescribed standards must work out a programme to eliminate and control the pollution, and report such programme to the environmental protection department of the local People's government at or above the county level for the record.

Article 16 Where the water pollutant discharge standards have been reached but cannot ensure the attainment of the water environment quality standards for water bodies, the People's governments at or above the provincial level may establish a system for controlling the total quantity of major pollutants discharged, and practise a system for determining the quantity of such major pollutants discharged among enterprises which are responsible for reducing the quantity of pollutants discharged. The State Council shall formulate specified measures therefor.

Article 17 The environmental protection department of the State Council may, in consultation with the water conservancy administration department under the State Council and the relevant People's government at the provincial level, and in accordance with uses and functions of water bodies of major river basins designated by the state and with local economic and technological conditions, set the water environmental quality standards applicable to provincial boundary water bodies of such major river basins, and report to the State Council and implement them after approval.

Article 18 The working organs for water resource protection of major river basins designated by the state shall be responsible for monitoring the state of environmental quality of provincial boundary water bodies within their respective river basin areas, and report the monitoring results in time to the environmental protection department and the water conservancy administration department of the State Council; if a leading organ for water resource protection of the river basin has been established with the approval of the State Council, the monitoring results shall in time be reported thereto.

Article 19 Urban sewage shall be disposed of in a centralized way.

Competent departments under the State Council and local People's governments at various levels must incorporate into their plans of municipal construction the protection of urban water sources and the prevention and control of urban water pollution, construct and perfect municipal drainage systems, and construct urban sewage treatment facilities in a planned way, in order to strengthen the comprehensive improvement of urban

http://english.mep.gov.cn/Policies_Regulations/laws/environmental_laws/200710/t200... 2009-10-5 
water environment.

Urban sewage treatment facilities shall, according to the state provisions, be used to provide paid service of sewage treatment for pollutant dischargers, and the fee for sewage treatment shall be collected to ensure the normal operation of sewage treatment facilities. Where sewage is discharged into urban sewage treatment facilities and the fee for sewage treatment has been paid therefor, the discharge fee shall not be levied. The income derived from the fee for sewage treatment so collected must be used for the construction and operation of urban sewage treatment facilities and may not be appropriated for other purposes.

The State Council shall formulate specific measures for the collection of the sewage treatment fee, and for the management and utilization of urban sewage treatment facilities.

Article 20 People's governments at or above the provincial level may delineate protected zones for surface sources of domestic and drinking water according to law. Such protected zones include the first and other classes protected zones. Specific water and land areas in the vicinity of intakes at a surface source for domestic and drinking water may be delineated as a first class protected zone, and those water and land areas outside the first class protected zone be delineated as other class protected zone. Various classes protected zones shall have their definite geographical boundaries.

The discharge of waste water into water bodies at the first class protected zones for surface sources of domestic and drinking water shall be prohibited.

Tours, swims and other activities which might cause pollution to domestic and drinking water bodies within the first class protected zones shall be prohibited.

Any new construction project or expansion unrelated to water supply facilities and to the protection of water sources within the first class protected zones for surface sources of domestic and drinking water shall be prohibited.

People's governments at or above the county level shall, according to their limits of authorities specified by the State Council, order to dismantle or improve within a prescribed time period those sewage outfalls already set up within the first class protected zones for surface sources of domestic and drinking water.

The protection of domestic and drinking groundwater sources shall be strengthened.

The State Council shall formulate specific measures for the protection of domestic and drinking water sources.

Article 21 In case of emergency, such as the severe pollution of a domestic and drinking water source which 
threatens safe water supply, the relevant environmental protection department shall, with the approval of the People's government at the corresponding level, take compulsory emergency measures, including ordering the enterprises or institutions concerned to reduce or stop the discharge of pollutants.

Article 22 Enterprises shall adopt clean production techniques which are efficient in the use of raw materials and discharge small quantity of pollutants, and shall strengthen the management to reduce the water pollutants generated.

The state establishes a system for eliminating those backward production techniques and equipment, which cause severe pollution to water environment.

The competent comprehensive administrative department of economy under the State Council shall, in consultation with departments concerned under the State Council, announce a catalogue of techniques which cause severe pollution to water environment and of which the adoption is to be prohibited upon the expiration of a prescribed time period, as well as a catalogue of equipment which causes severe pollution to water environment and of which the production, sale, importation and use are to be prohibited upon the expiration of a prescribed time period.

Producers, marketers, importers or users must, within the time limit specified by the competent comprehensive administrative department of economy in consultation with departments concerned under the State Council, stop respectively the production, sale, importation or use of equipment listed in the catalogue mentioned in the preceding paragraph. Adopters of production techniques must, within the time limit specified by the competent comprehensive administrative department of economy in consultation with departments concerned under the State Council, stop the adoption of techniques listed in the catalogue mentioned in the preceding paragraph.

Equipment already eliminated according to the provisions in two preceding paragraphs may not be transferred to others for use.

Article 23 The state prohibits the establishment of any new small size enterprise engaging in chemical paper pulp making, printing and dyeing, dyestuff, hide processing, electroplating, oil refining or agricultural chemical without measures for the prevention and control of water pollution, and other enterprises which may cause severe pollution to water environment.

Article 24 If a unit discharging pollutants has caused severe pollution of a water body, it shall be ordered to eliminate and control the pollution within a certain period.

For enterprises and institutions directly under the jurisdiction of the Central Government or the People's government of a province, autonomous region, or municipality directly under the Central Government, the 
determination of a deadline for elimination or control of pollution shall be recommended by the environmental protection department of the People's government of the province, autonomous region or municipality, and be reported to the People's government at the corresponding level for decision. For enterprises and institutions under the jurisdiction of a People's government at or below the city or county level, such recommendation shall be made by the environmental protection department of the people's government at the corresponding level for decision. The pollutant discharging units shall accomplish the elimination or control of pollution within the specified period.

Article 25 Environmental protection departments and relevant supervisory and management departments of People's governments at various levels shall be empowered to make on site inspections of units under their jurisdiction that discharge pollutants. The units being inspected shall report the situation truthfully and provide the necessary information. The inspecting authorities shall have the obligation to keep the technological and trade secrets of the units inspected.

Article 26 Water pollution disputes involving different administrative areas shall be settled through negotiation between or among local People's governments involved therein, or through co ordination by their common higher People's government.

\section{CHAPTER IV PREVENTION OF SURFACE WATER POLLUTION}

Article 27 No new sewage outfalls shall be set up in the protected zones for domestic and drinking water sources, water bodies at scenic or historic sites, important fishery water bodies and other water bodies of special economic or cultural value. When new sewage outfalls are set up in the vicinity of such protected zones, the water bodies within those zones must be ensured against pollution.

Measures for the elimination or control of pollution shall be taken for any sewage outfall which was established before the promulgation of this Law and which discharges pollutants in excess of the limits set by national or local standards. Outfalls endangering drinking water sources shall be relocated.

Article 28 Where any pollutant discharging unit, as a result of an accident or other exigency, discharges pollutants in excess of normal quantities, thereby causing or threatening to cause a water pollution accident, it shall immediately take emergency measures, inform such units as are likely to be endangered or damaged by the water pollution and report the case to the local environmental protection department. Ships that have caused any pollution accident shall report the case to the nearest navigation administration office for its investigation and disposal.

In the case of any pollution accident caused to fisheries, the fisheries administrative and superintendency agencies shall be responsible for its investigation and disposal.

http://english.mep.gov.cn/Policies_Regulations/laws/environmental_laws/200710/t200... 2009-10-5 
Article 29 The discharge of any oil, acid or alkaline solutions or deadly toxic liquid waste into any water body shall be prohibited.

Article 30 The washing in any water body of vehicles or containers which have been used for storing oil or toxic pollutant shall be prohibited.

Article 31 The discharge or dumping into any water body, or the direct underground burying of deadly toxic soluble slag, tailings, etc., containing such substances as mercury, cadmium, arsenic, chromium, lead, cyanide and yellow phosphorus, is prohibited.

Sites for depositing deadly toxic soluble slag, tailings, etc., shall be made waterproof and protected against seepage and leaking.

Article 32 The discharge or dumping of industrial waste residues, urban refuse or other wastes into any water body shall be prohibited.

Article 33 The piling or depositing of solid wastes and other pollutants on beaches and bank slopes below the highest water level of rivers, lakes, canals, irrigation channels and reservoirs shall be prohibited.

Article 34 The discharge or dumping of radioactive solid wastes or of waste water containing any high- or medium- level radioactive substances into any water body shall be prohibited.

The discharge of waste water containing low level radioactive substances shall comply with the relevant national provisions and standards for radioactive protection.

Article 35 Where discharge of heated waste water into any water body is to be made, measures shall be taken to ensure that the temperature of the water body conforms to the water environment quality standards, so as to prevent any heat pollution hazard.

Article 36 Pathogen contaminated sewage can be discharged only after it is disinfected to meet the relevant national standards.

Article 37 The discharge of industrial waste water or urban sewage into agricultural irrigation channels shall be made only with the assurance that the water quality at the nearest irrigation intake downstream conforms to the agricultural irrigation water quality standards.

When industrial waste water or urban sewage is used for irrigation, attention shall be paid to guarding against 
pollution of the soil, groundwater or agricultural products.

Article 38 The application of pesticides shall comply with the state provisions and standards for their safe use.

Transportation and storage of pesticides and disposal of expired or ineffective pesticides shall be strictly controlled to prevent water pollution.

Article 39 The agricultural administration department and other relevant departments of a local People's government at or above the county level shall take measures to instruct agricultural producers to apply chemical fertilizers and pesticides in a scientific and rational manner, and control the excessive use of chemical fertilizers and pesticides, so as to prevent water pollution therefrom.

Article 40 The discharge of oil bearing waste water or domestic sewage from ships shall comply with ship pollutant discharge standards. Ocean navigating ships, on entering inland rivers or harbours, shall observe ship pollutant discharge standards for inland rivers.

Residual oil or waste oil of ships must be recovered, and its discharge into any water body shall be prohibited. The dumping of ship refuse into any water body shall be prohibited.

In the process of loading and transporting oils or toxic cargoes, ships must be safeguarded against spillage and leakage and against such cargoes falling into the water, so as to prevent water pollution therefrom.

\section{CHAPTER V PREVENTION OF GROUND WATER POLLUTION}

Article 41 Enterprises and institutions shall be prohibited from discharging waste water containing toxic pollutants or pathogens or dumping other wastes into seepage wells, cesspools, crevices or karst caves.

Article 42 At places where no satisfactory impervious strata exist, enterprises and institutions shall be prohibited from using ditches, pits or ponds which are without safeguards against seepage for conveyance or storage of waste water containing toxic pollutants or pathogens, or of other wastes.

Article 43 In exploiting groundwater from multiple aquifers, layered exploitation shall be resorted to if water quality differs greatly from one aquifer to another. Combined exploitation of artesian water and polluted phreatic water shall not be permitted.

Article 44 While constructing underground engineering facilities or carrying out prospecting, mining or other underground activities, protective measures shall be taken for prevention of groundwater pollution.

http://english.mep.gov.cn/Policies_Regulations/laws/environmental_laws/200710/t200... 2009-10-5 
Article 45 Artificial recharge of groundwater shall not be deleterious to groundwater quality.

\section{CHAPTER VI LEGAL LIABILITY}

Article 46 Any violator of this Law shall, according to the circumstances of the case, be warned or fined by the competent environmental protection department or the navigation office of the competent transportations department for any of the following:

(1) refusing to report or submitting a false report on items for which registration is required by the environmental protection department of the State Council for the discharge of pollutants;

(2) refusing an on site inspection by the competent environmental protection department or supervisory and management department, or resorting to deception;

(3) storing, piling, abandoning, dumping or discharging any pollutant or waste in violation of Chapters IV and V of this Law; or

(4) failing to pay, as provided for by the state, the fee for pollutant discharge or for excess discharge.

The amount of the fine and the procedure for its imposition shall be stipulated in the rules for the implementation of this Law.

Article 47 If, in violation of the provisions of the third paragraph of Article 13 in this Law, a construction project is put into operation or to use when its facilities for the prevention and control of water pollution have not completed or fail to meet the state specified requirements, the environmental protection department that approved the environmental impact statement of the said project shall order the violator to stop the operation or use of the project and may concurrently impose a fine.

Article 48 If a pollutant discharging unit, in violation of the provisions of the second paragraph of Article 14 in this Law, intentionally does not keep its water pollutant treatment facilities in normal use, or dismantles or leaves idle such facilities without approval of the environmental protection department, thereby discharging pollutants in excess of prescribed standards, the environmental protection department of a local People's government at or above the county level shall order it to restore such facilities to the normal use, or set a time limit for it to reinstall and reuse such facilities, and concurrently impose a fine.

Article 49 If anyone, in violation of the provisions of the fourth paragraph of Article 20 in this Law, establishes within the first class protected zones for surface source of domestic and drinking water any new construction or expansion project unrelated to water supply facilities and to the protection of water sources, the People's 
government at or above the county level shall, according to its limit of authorities specified by the State Council, order the violator to suspend operations or close down.

Article 50 If anyone, in violation of the provisions of Article 22 in this Law, produces, sells, imports or uses equipment, or adopts techniques, which have already been prohibited, the competent comprehensive administrative department of economy of the People's government at or above the county level shall order the violator to make correction; if the circumstances are serious, the said department shall propose and report to the People's government at the corresponding level for an order of suspension of operations or shutdown issued within its limit of authorities specified by the State Council.

Article 51 If anyone, in violation of the provisions of Article 23 in this Law, establishes any small size enterprise without measures for the prevention and control of water pollution, thereby causing severe pollution to water environment, the local People's government at the city or county level or the higher people's government shall order to shut down such enterprise.

Article 52 An enterprise or institution which has caused severe pollution to water bodies but has failed to accomplish its elimination by the deadline as required shall, as provided for by the state, pay twice or more the fee for excess discharge; in addition, a fine may be imposed in accordance with the consequent damage and loss, or the said enterprise or institution may be ordered to suspend operations or close down.

The fine shall be decided by the competent environmental protection department. Orders for the suspension of operations or the shutdown of enterprises and institutions shall be issued by the local People's government which set the deadline for the elimination of pollution. Orders for the suspension of operations or shutdown of enterprises and institutions under the jurisdiction of the Central Government shall be submitted to and approved by the State Council.

Article 53 A pollutant discharging unit which violates this Law, thereby causing a water pollution accident, shall be fined according to the consequent damage and loss by the competent environmental protection department of the local people's government at or above the county level in the place where the accident takes place.

In the case of a pollution accident caused to fisheries or caused by vessels, the competent fisheries administration and superintendency agency or the navigation office of the competent transportation department in the place where the accident takes place shall impose a fine respectively according to the consequent damage and loss.

If the circumstances are serious in a water pollution accident, the persons responsible shall be subject to disciplinary sanction by the unit to which they belong or by a higher competent authority. 
Article 54 A party refusing to accept the decision of administrative sanction may bring suit before a People's court within 15 days from the date of receiving the notification. If upon the expiration of the period the party neither brings suit nor complies with the decision, the organ which imposed the sanction may apply to the People's court for compulsory enforcement.

Article 55 The unit which has caused a water pollution hazard has the responsibility to eliminate it and make compensation to the unit or individual that suffered direct losses.

A dispute over liability to make compensation or the amount of compensation may, at the request of the parties, be settled by the competent environmental protection department or by the navigation office of the competent communications department. If a party refuses to accept the decision, he may bring suit before a People's court. The party may also bring suit before the People's court directly.

If the water pollution losses are caused by a third party intentionally or negligently, the third party shall be liable to make compensation.

The unit discharging pollutants shall bear no liability for water pollution losses occasioned by the victim's own fault.

Article 56 If water pollution losses result entirely from irresistible natural disasters which cannot be averted even after reasonable measures have been promptly taken, the party concerned shall be exempted from liability.

Article 57 Should any violation of this Law give rise to a serious water pollution accident leading to any grave consequence of heavy public or private property losses or serious personal injury or death, the person responsible for such violation may be investigated for criminal liability by application of Article 115 or 187 of the Criminal Law.

Article 58 Personnel conducting supervision and management of environmental protection or other relevant state personnel who abuses his power, neglects his duty or engages in malpractices for personal gains shall be given disciplinary sanction by the unit to which he belongs or the competent higher authorities: if his act constitutes a crime, he shall be investigated for criminal responsibility according to law.

\section{CHAPTER VII SUPPLEMENTARY PROVISIONS}

Article 59 With regard to individual businesses that discharge pollutants into water bodies and cause severe pollution, standing committees of the people's congresses of the provinces, autonomous regions and municipalities directly under the Central Government shall formulate measures therefor in accordance with the principles in the provisions of this Law.

http://english.mep.gov.cn/Policies_Regulations/laws/environmental_laws/200710/t200... 2009-10-5 
Article 60 For the purpose of this Law, the definitions of the following terms are:

(1) "Water pollution" means the introduction into a water body of any substance which alters the chemical, physical, biological or radioactive properties of the water in such a way as to affect its effective use, endanger human health, damage the ecosystem or be deleterious to water quality.

(2) "Pollutant" means a substance that is capable of causing water pollution.

(3) "Toxic pollutant" means a pollutant that, when ingested by organisms directly or indirectly, leads to diseases, abnormal behaviour, genetic mutation, physiological functional disturbance, organism deformity or death of the organisms themselves or their offspring.

(4) "Oil" means any kind of oil or its refined products.

(5) "Fishery water bodies" means those parts of water bodies designated for the spawning, feeding, wintering or migratory passage of fish or shrimp, and for breeding fish, shrimp or shellfish or growing algae.

Article 61 The environmental protection department of the State Council shall, on the basis of this Law, formulate rules for its implementation, which shall be put into effect after being submitted to and approved by the State Council.

Article 62 This Law shall come into force on November 1,1984.

Source:

【 Big Medium-sized Small 】

【Print】【Close】

Sponsored by MEP, Address: No.115 Xizhimennei Nanxiaojie, Beijing (100035)

Telephone Numbers for Administrative Offices

http://english.mep.gov.cn/Policies_Regulations/laws/environmental_laws/200710/t200... 2009-10-5 